Çiçek, M. ve Alcellat, N. (2014). Ilköğretim Türkçe dersi kitaplarındaki Türkçe yanlışları ve eksiklikler üzerine bir inceleme. Ana Dili Eğitimi Dergisi. 2(4), 120-134.

Ana Dili Eğitimi Dergisi
Journal of Mother Tongue Education
ADED - JOMTE
www.anadiliegitimi.com

\title{
İlköğretim Türkçe Dersi Kitaplarındaki Türkçe Yanlışları ve Eksiklikler Üzerine Bir İnceleme*
}

\author{
Mehmet Çiçek ${ }^{* *}$ \\ Nesibe Alcellat ${ }^{* * *}$ \\ Özet
}

Bu çalışmada ilköğretim 5, 6, 7, 8. Sınıf Türkçe dersi kitapları incelenmiştir. İncelemede kitaplardaki dil ve anlatım, dil bilgisi başta olmak üzere hata ve yanlışlıklar ele alınmış; kitaplardaki metinlerin okunabilirlik ve tümce uzunlukları açısından öğrenci düzeyine uygun olup olmadığı sorgulanmıştır. İnceleme sonucunda, ilköğretim Türkçe dersi kitaplarında gözden kaçan bazı yazım yanlışlarının yanı sıra öğrenci düzeyinin üzerinde metinler bulunduğu gözlemlenmiştir. Söz konusu metinlerdeki en büyük sorunu; anlaşılması, öğrenilmesi zor sözcükler oluşturmaktadır. Öğrencilerin bu sözcükleri sözlüklerden bakarak bile kavramalarının zor olduğu düşünülmektedir. Kitaplardaki "biçimsel görünüm" ve "bilimsel içerik" inceleme dışında tutulmuştur. Çalışmada üzerinde durulan diğer bir konu da anadili bilinci ve bu bilincin kazandırılmasına yönelik metinlerin nicelik yönünden incelenmesi olmuştur. Anadili bilinci kazandırmaya yönelik metinlerin incelenmesinde MEB yayınları özellikle tercih edilmiş; ilgili yayınlardaki metinlerin nicelik olarak yetersiz olduğu sonucuna varılmıştır. Bu yetersizliğin 8. Sınıf Türkçe dersi kitabında daha da belirgin olduğu gözlemlenmiştir. Çalışma sonunda anadili bilinci kazandırmaya yönelik bazı görüş ve önerilere yer verilmiştir.

Anahtar Sözcükler: Türkçe dersi kitapları, Dil yanlışları, Anadili bilinci

\section{A Research on Faults in Turkish Language Course Books for the 5, 6, 7 and 8th Grades}

\begin{abstract}
In this study, Turkish language course books of the 5, 6, 7 and 8th grades were analyzed, and the following questions were the main concerns of the study: In the Turkish language course books prepared for the 5, 6, 7 and 8th grades;- Are there linguistic and grammatical faults and/or errors?- Are there too long sentences which are very difficult to read and understand for pupils? It was observed that in Turkish language course books for the 5, 6, 7 and 8th grades there are some important faults and errors. There are also some long texts whose readability is unacceptable. On the other hand, there are some difficult words to understand for pupils' school level. It is thought that for pupils it is difficult to learn those words even if they look them up in a dictionary. The scientific content and aspectual shape in the textbooks were ignored. Another point considered as important was the determination of the texts related to mother tongue consciousness: These texts were analyzed quantitatively and qualitatively and it was found that they (MEB Turkish course books) were insufficient. This failure was more striking in the 8 th grade Turkish language course book. At the end of the study some points of views and propositions related to the mother tongue acquisition consciousness were given.
\end{abstract}

Keywords: Turkish language course books, Linguistic faults/errors, Mother tongue consciousness.

\footnotetext{
* Bu çalışma, 19-21 Haziran 2014 tarihlerinde Muğla Sıtkı Koçman Üniversitesi'nde düzenlenen 7. Uluslararası Türkçenin Eğitimi - Öğretimi Kurultayı'nda sunulan bildirinin genişletilmiş halidir.

** Doç. Dr., Gaziantep Üniversitesi Eğitim Fakültesi Türkçe Eğitimi Bölümü, Gaziantep.

E-posta: g.antepli@gmail.com

${ }^{* * *}$ Y. Lisans Öğr., Gaziantep Üniversitesi Eğitim Bilimleri Enstitüsü, Türkçe Eğitimi ABD, Gaziantep.

E-posta: nesibeefe1991@gmail.com
} 


\section{Giriş}

Dil ve iletişimle ilgili akla gelen ilk yargılardan biri de olsa, "dil bir araçtır" demek daha doğrusu bir şeyi sadece araç konumuna indirgemek çok doğru bir yaklaşım olmasa gerek. Gerçekte dil ile neler yapılabildiğini az çok herkes bilir; ancak yinelemekte fayda görüyoruz, dili kullanarak;

- Sosyal bir varlık oluruz,

- Soyut somut her şeyi; duygularımızı, sevinçlerimizi, üzüntülerimizi, geçmişimizi, geleceğimizi başkalarıyla paylaşabiliriz. İletişim ortamında fiziksel olarak var olmayan soyut, somut her şeyi, ses ve yazı gibi fazla çaba gerektirmeyen gösterenler aracılığılla, bulunduğumuz ortama taşır; onları yokken adeta var edip iletişim amacıyla kullanırız,

- Geçmişimizi öğrenir, geleceğe aktarırız,

- Edebiyatçılarımız şiirler, romanlar, hikâyeler, vb. yazar; gazeteciler mesleklerini icra ederler,

- Bir başbakan bir genelge yayınlar, bir rektör açılıs konuşması yapar, bir vatandaş mahkemede dava açar ya da bir hâkim bir vatandaşın hayatını tümünden değiştirecek kararlar verir...

Burada, ortak paydası dil ve iletişim olan bu örneklerin binlercesini saymak elbette ki mümkündür; ancak biz dil ve dili kullanmak kavramını okuryazar olmak anlamında değil; insan olmak, birey olmak, var olmak ve sahip olduğu dili kadar yaşamak anlamında kullanıyoruz. Bu bağlamda insan, dili kadardır ve dili kadar vardır demek yanlış bir yargı olmasa gerektir. Bu yönüyle Türkçemiz ve Türkçenin eğitimi-öğretimi, tıpkı her ulusun kendi dili için olduğu gibi, Türk ulusu için de var olmakla yok olmak arasındaki kararda belirleyici en önemli unsur oluyor.

Dil ile ilgili eğitimin ilk olarak ailede verildiği söylense de bunun her zaman böyle olmadığını ya da nitelik ve nicelik açısından sorunlu olduğunu kestirmek zor olmasa gerek. Nitekim sosyoekonomik durumu çok iyi, kültürlü ve eğitimli ailelerde yetişen bireyler bile okulun sunduğu eğitim olanaklarından gereği gibi yararlanmadıklarında Türkçenin doğru ve etkili kullanımıyla ilgili sorunlarla karşı karşıya kalacaklardır. İşte bu sorunlar aşılması gerektiğinde doğaldır ki akla ilk olarak eğitimöğretim, ilköğretim ve tabii ki Türkçe dersi ve Türkçe dersi kitapları ${ }^{1}$ gelecektir. İşte bu yazının asıl konusunu da az önce saydığımız unsurlardan son ikisi yani Türkçe dersi ve Türkçe dersi kitapları², daha doğrusu Türkçe dersi kitaplarının Türkçesi oluşturuyor.

\footnotetext{
${ }^{1}$ Burada "Türkçe Dersi Kitabı" derken öğrenci çalışma kitaplarını da kastediyoruz.

${ }^{2}$ Bilebildiğimiz kadarıyla bütün Türkçe dersi kitaplarında, kitap adı olarak Türkçe dersi kitabı değil de Türkçe ders kitabı ifadesi kullanımaktadır. Ingilizce ders kitabı ya da Fransızca ders kitabı dendiğinde, o ders kitabının -ki bu kitap bir coğrafya ya da matematik kitabı da olabilir-, o dilde yani Ingilizce veya Fransızca olduğu anlaşılmaktadır. Oysa Ingilizce dersi kitabı, Fransızca dersi kitabı ya da Türkçe dersi kitabı dendiğinde, bunun doğrudan doğruya o dilin eğitim-öğretimiyle ilgili olduğu anlaşılacağından sıfat değil de isim tamlamasının tercih edilmesinin daha doğru olacağını düşünmekteyiz.
} 


\section{Ders Kitabı Kavramı}

Eğitim-Öğretim dendiğinde, ders kitapları; akıllara ilk gelen, yeri ve önemi konusunda herkesin hemfikir olduğu paydaşlardandır.

Bilindiği üzere, yenilenen (2005) ilköğretim ikinci kademe Türkçe dersi öğretim programıyla eğitimde temel alınan görüş davranışsal yaklaşımdan yapılandırmacı yaklaşıma dönmüştür. Bu dönüşüm eğitimde en sık kullanılan materyal olan ders kitaplarının yeniden gözden geçirilmesini ve yapılandırımasını gerektirmiştir. Bu yeni yapılandırılmayla beraber program önceden öğretmen merkezliyken yenisinde öğrenci merkezli olarak tasarlanmıştır: "Değişen ilköğretim programının temel özelliği, dayandığı yapılandırmacı yaklaşım gereği, öğrencilere bilgi ezberletmemesi, öğretme ve öğrenme sürecinin her aşamasına aktif olarak katılmasını sağlaması, uyaranları yorumlamalarını, anlamlandırmalarını ve bilgileri bizzat kendilerinin yapılandırarak öğrenmelerini sağlayıcı nitelikte olmasıdır" (Ekinci ve ark., 2011:1 ). Görüldüğü gibi yapılandırmacı yaklaşımın bir gereği olarak öğrenci; ezberden uzak duracak, ders kitabında bulduğu bilgiyi yorumlayacak, anlamlandıracak ve yapılandırarak öğrenecektir. Haliyle, öğrencinin yorumlayacağı, anlamlandıracağı ve yapılandırarak öğreneceği şey;

a) Kuşkuya, yanlış anlamalara yer vermeyecek biçimde doğru ve güncel olmalıdır,

b) Bilginin veriliş biçimi de doğru olmalıdır. Örneğin; sözcük yazım yanlışları, anlatım bozuklukları, noktalama işaretlerinde yanlışlıklar, vb. olmamalıdır.

Burada bu listeyi uzatmak mümkün olsa da -herkes tarafından iyi bilinen şeyler olduğu içinayrıntılara girmeyi gerekli görmüyoruz; ancak bu arada ders kitaplarının -öncelikle ders kitabı olaraköğrenciye sağladığı yararları kavramak için şu bilgilere de dikkat çekmek istiyoruz:

“(1) Ders kitabı, öğretmenin sözlü dersini tamamlar,

(2) Ders kitabı, sözlü öğretimin eksikliklerini giderir,

(3) Bilgiler arasındaki bağlantısızıkları ortadan kaldırır,

(4) Öğrenilen bilgileri tekrar gözden geçirmeyi mümkün kılar,

(5) Ders kitabından çalışılırken öğrenci, daha aktif düşünen ve sorumluluk hisseden bir yapı içindedir,

(6) Öğrenciyi farklı soru tipleri, sorularla ilgili farklı çözüm yolları ve konu anlatımında ileriye sürülen farklı yaklaşımlarla yüz yüze getirir,

(7) Öğretimi sıkıcılıktan kurtarır, ilginin devamını sağlar,

(8) Ders kitabı öğrencinin derse önceden hazırlanmasını sağlar." (Duman, Karakaya, Çakmak, Eray, Özkan, 2001; Akt. Dane, Doğar, Balkı, 2004: 3).

Ders kitaplarının yararlarına ilişkin burada sıralanan görüşlerin hedefine ulaşması, ulaştırılması için en önemli unsur yani ortak payda, Türkçe olmaktadır. Burada "Türkçe" derken iki şeyi özellikle önemsiyoruz: 
1. Öğrenci; okuma, anlama, kavrama açısından yeterli düzeyde Türkçe bilgi ve becerisine sahip olmalıdır;

2. Ders kitabının kendisinin doğru bilgilere sahip olmasının yanında bu bilgileri de doğru biçimde vermesi; bir başka ifadeyle söylersek ders kitabının Türkçesi konusunda da gerekli titizliğin ve hassasiyetin gösterilmiş olması gerekir.

Buraya aldığımız bu iki madde arasında şöyle bir bağlantı var: îkinci maddeden başlar ve tersinden düşünürsek; hatalarla dolu, gelişigüzel hazırlanmış ve Türkçesi özensiz bir Türkçe dersi kitabı ile Türkçe öğretilmeye çalışılırsa başarı yüzdesi çok çok düşecek bu da birinci maddede sözünü ettiğimiz bilgi ve becerilerin kazan(dır)ılmasını sekteye uğratacaktır. Hatta Türkçeyle ilgili bilgi ve beceri sorunu sadece kendisi ile sınırlı kalmayıp eğitim-öğretimin dil ve iletişimle ilgili her noktasını ilgilendirebilecektir. Örneğin, anadili bilgi ve becerisinin yabancı dil öğrenimindeki başarı ve/veya başarısızlıkla da doğrudan ilintili olduğu bilinmektedir (Çiçek \& Bağçeci, 2013).

\section{İlköğretim Türkçe Dersi Kitapları ve Bazı Gözlemler}

Kuşkusuz her ders kitabı önemli ve gereklidir; ancak anadili bilinci ${ }^{3}$ açısından Türkçe dersi kitapları ve bu kitaplarla hedeflenen kazanımlar ayrı bir yere ve öneme sahiptir.

Alanı ne olursa olsun ders kitabı incelemelerinde sırasıyla;

Biçimsel görünüm,

Bilimsel içerik,

Dil ve anlatım,

belli ölçütlere göre değerlendirilmektedir. Türkçe dersi kitapları açısından "biçimsel görünüm" söz konusu olduğunda belli bir düzeyin (Arı, 2010) yakalandığı söylenebilir. Biçimsel görünüme koşut olarak değerlendirilen bir başka olgu da Türkçe dersi kitaplarında kullanılan resimlerdir. İşeri (2010: 85) konunun önemiyle ilgili şunları söylemektedir: "iyi çizilmiş bir resim çocuğun metnin iletisini kavraması yanında doğrudan olmasa da dolaylı olarak ona düşündürmeyi ve estetik zevki aşılamayı da sağlayacaktır. Birey, işitme ve görme duyusu aracıllı̆ıyla kendine ileride yarayacak, kişiliğini oluşturacak bilgilere ulaşır. Böylelikle, Milli Eğitimin genel amaçlarına uygun bireylerin yetişmesinde resimlemenin önemi de kendiliğinden ortaya çıkmış olur. Resimlerle desteklenmiş kitaplar, çocuğun kendi deneyimleri aracılığıyla kazandığı bilgilerin güçlenmesini sağlar. Bu yönüyle de çocukta özgüven duygusunu pekiştirir". Türkçe dersi kitaplarında kullanılan resimlerin incelenmesi ve bunların göstergebilimsel görünümlerini burada ele almayacağız; bununla beraber, incelediğimiz ders kitaplarında gördüğümüz görsel içeriğin yeterli düzeyde olduğunu söyleyebiliriz.

Bilimsel içerik ve biçimsel görünümle karşılaştırıldığında, dil ve anlatımın; Türkçe dersi kitapları için daha da dikkat edilmesi gereken bir özellik olduğunu düşünüyoruz. Çok iyi bir bilimsel

\footnotetext{
${ }^{3}$ Anadili bilinci konusu ileride ayrıntılı olarak ele alınacaktır.
} 
içerik, çok güzel bir biçimsel görünüm sunulsa da bu sunumun aracısı durumundaki dil ve anlatımda hatalar yapılır, tutarsızlıklar sergilenirse ortaya iki büyük sorun çıkacaktır:

1- Bilimsel içerikle hedeflenen kazanım gerçekleşmeyecek; biçimsel görünüm sadece bir görsellikten ibaret olacaktır,

2- Dil ve anlatımın kendisi aslında temel dil becerilerini kazandırmayı hedeflediği için çözüm sunacak yerde sorun yumağına dönüşecektir.

Biz burada ders kitaplarındaki dil ve anlatımı önceleyen bir bakış açısı benimseyeceğiz. Şimdi dil ve anlatımla ilgili, Türkçe dersi kitaplarında hatalı ya da eksik olduğunu düşündüğümüz bazı noktaları yakından görelim.

\section{Dil ve Anlatımla İlgili Bazı Eksiklikler}

Aşağıdaki tabloda da görüleceği üzere, göze çarpan hata ve eksiklikler bilgi eksikliği değildir; daha çok özen göstermemekten ve dikkatsizlikten kaynaklanan yanlışlıklardır:

Tablo-1 Dil ve anlatımla ilgili bazı eksiklikler

\begin{tabular}{|c|c|}
\hline Yeri & Yanlışık, Hata ve/veya Eksiklik ve Açıklaması \\
\hline $\begin{array}{c}\text { Türkçe } 5 \text { (Alacalı, 2013: } \\
\text { 14) Aslında Hepimiz } \\
\text { Zekiyiz adlı metinde... }\end{array}$ & $\begin{array}{l}\text { "Matematik sorularını en hızlı onlar mı yaparlar?" tümcesi anlatım açısından } \\
\text { sıkıntııdır; çünkü soru çözülür, yapılmaz. } \\
\text { Eğer dikkatli olunmaz, gerekli özen gösterilmezse; öğrenciler öğrenimlerinin ilk } \\
\text { aşamalarından itibaren bu yanlışıkları doğru zannedecekler, bu da ileride telafisi } \\
\text { mümkün olmayan anlatım bozukluğu sorunlarına yol açacaktır. Nitekim anlatım } \\
\text { bozuklukları konusundaki sorunların başında, kullanımına alışılmış yanlışlıklar } \\
\text { gelmektedir. }\end{array}$ \\
\hline $\begin{array}{l}\text { Türkçe } 5 \text { (Alacalı, 2013: } \\
\text { 59) Düssler ve Teknoloji } \\
\text { adlı metinde... }\end{array}$ & $\begin{array}{l}\text { Metindeki bazı sözcük ve ifadeler öğrencilerin düzeylerine uygun } \\
\text { gözükmemektedir: "android", "bilim kurgu", "angarya iş", "düş gücü geniş } \\
\text { bireyler" gibi sözcük ve ifadeler; öğrenciler henüz somut işlemler döneminde } \\
\text { olduklarından, soyut/somut anlama-kavrama açısından güçlük yaratabilir. }\end{array}$ \\
\hline $\begin{array}{l}\text { Türkçe } 5 \text { (Alacalı, 2013: } \\
\text { 74) Tükenmeyen } \\
\text { Kalemler adlı } \\
\text { metinde... }\end{array}$ & $\begin{array}{l}\text { "Anlatmaya önce mürekkepten başlayalım: Mürekkebin bulunuşu insanoğlunun } \\
\text { kâğıtla tanışmasına da neden oldu" tümcesinde daha çok anlam yönüyle olumsuz } \\
\text { tümcelerde karşılaştığımız neden olmak yerine sağlamak kullanılarak tümce şu } \\
\text { şekilde yazılabilirdi: “(...) insanoğlunun kâğıtla tanışmasını da sağladı." } \\
\text { Anlatım bozuklukları ile ilgili sorunların başında, kullanımına alışılmış yanlışlıklar } \\
\text { geldiği için ayrıntılar konusunda dikkatli olunmalıdır. }\end{array}$ \\
\hline $\begin{array}{l}\text { Türkçe } 6 \text { (Karabıyık, } \\
\text { 2013: 17-21) Tünek } \\
\text { Ahmet adlı metinde... }\end{array}$ & $\begin{array}{l}\text { Metinde geçen “...nazlı bel kırışlarını seyre mi çıktın?” tümcesindeki "bel kırışları" } \\
\text { ifadesi 6. Sınıf öğrencileri tarafından anlaşılması zor bir ifadedir. Aynı zorluk } \\
\text { metinde geçen ve birçoğu denizcilikle ilgili olan şu sözcükler için de geçerlidir: } \\
\text { Zıpkın, Şilte, Mağrur, Alamet, Sünger, Çıkrık, Mecidiye, Tütsü, Yedi Kulaç, Hallaç, } \\
\text { Senet, Tirhandili, Seren, Çarmıklar, Apil, Güverte, Küpeşte, Pertavsız, Pruva. (Bu } \\
\text { sözcüklerle ilgili gözlemlerimiz sınıf ortamında ilgili metin üzerinde bilinmeyen } \\
\text { sözcük ve anlaşılmayan yerlerin bizzat } 6 \text {. sınıf öğrencilerine tespit ettirilmesine } \\
\text { dayanmaktadır.) Buradaki sözcüklerden bazılarını [apil, tirhandili, gület ("gület" } \\
\text { sözcüğü, TDK çevrimiçi sözlüğünde "ufak su birikintisi” biçiminde tanımlanmakta } \\
\text { bu da metne uymamaktadır!)] öğrenci sözlüklerde de bulamamaktadır. Öte } \\
\text { yandan metinde yer alan birçok tümce okunabilirlik yönüyle uzunluk açısından }{ }^{5} 6 \text {. } \\
\text { Sınıf öğrencileri için uygun değildir. Aynı metinde "Ahmet yalnız kayığına biner" } \\
\text { tümcesi de "Ahmet kayığına yalnız biner" olmalıydı. }\end{array}$ \\
\hline
\end{tabular}

\footnotetext{
${ }^{4}$ Noktalama işaretleri ve -varsa- yazım yanlışlarını da dil ve anlatımın bir parçası olarak görüyoruz.

${ }^{5}$ Okunabilirlik açısından sınıflara göre sözcük sayıları ve tümce uzunlukları için bkz. (Çebi, 2006: 117).
} 


\begin{tabular}{|c|c|}
\hline $\begin{array}{l}\text { Türkçe } 6 \text { (Karabıyık, } \\
\text { 2013: 103) Kar Tanesi } \\
\text { adlı metinde... }\end{array}$ & $\begin{array}{l}\text { "Bütün bir gece herkes Kar Tanesi'ni aramış ama bulamamışlar" tümcesinde } \\
\text { özneden kaynaklanan bir anlatım bozukluğu vardır. Tümcede bulunan iki } \\
\text { yüklemden birincisi olan "aramış" çekimli eyleminin öznesi "herkes" sözcüğüdür. } \\
\text { Fakat "herkes" sözcüğü aynı zamanda "bulamamışlar" çekimli eyleminin de öznesi } \\
\text { konumundadır. Bu durumda "Herkes bulamamışlar" gibi bir tümce ortaya } \\
\text { çıkmaktadır. Tümce şu şekilde düzeltilirse anlatım bozukluğu ortadan kaldırılmış } \\
\text { olacaktır: "Bütün bir gece herkes Kar Tanesi'ni aramış ama kimse (onu) } \\
\text { bulamamış." }\end{array}$ \\
\hline $\begin{array}{l}\text { Türkçe } 6 \text { (Karabıyık, } \\
\text { 2013: 105) Kar Tanesi } \\
\text { adlı metinde... }\end{array}$ & $\begin{array}{l}\text { Metnin sonunda yer alan "hazırlayan" anlamındaki "hzl." kısaltması TDK'nın } \\
\text { belirlediği kısaltma ile uyuşmamaktadır; doğrusu "haz." biçiminde olmalıdır. }\end{array}$ \\
\hline $\begin{array}{l}\text { Türkçe } 7 \text { (Yangın ve } \\
\text { ark., 2012: 89) Anne } \\
\text { Ben Çocuk Değilim! adlı } \\
\text { metinde... }\end{array}$ & $\begin{array}{l}\text { Metinde geçen, "Canım, 'baba', ve 'ağabey' sözcükleri, ilk sözlüğü yazan Kaşgarlı } \\
\text { Mahmut'un Divan-ü Lügat-it-Türk'ünde bile yer almıştır, eminim", tümcesinde } \\
\text { sözcükler birbirine "ve" bağlacıyla bağlanmasına rağmen, 'baba' sözcüğünden } \\
\text { sonra yanlışlıkla virgül kullanılmıştır. }\end{array}$ \\
\hline $\begin{array}{l}\text { Türkçe } 7 \text { (Yangın ve } \\
\text { ark., 2012: 92-93) } \\
\text { Balıkçıl adlı metinde... }\end{array}$ & $\begin{array}{l}\text { Metinde geçen “Muntazam”, “Namizaç”, "Müşkülpesent”, "Değme” sözcükleri } \\
\text { anlaşılması güç sözcüklerdir. Sözcüklerin kavram alanlarına ve öğrenci düzeyine } \\
\text { uygunluklarına bakıldığında, bunlardan ilki sözlük; sonraki ikisi sözlük ve öğretmen; } \\
\text { üçüncüsü ise ancak özel bir yaklaşımla öğretilebilir. Böyle bir yaklaşım ve öğretim } \\
\text { süreci de yapılandırmacı olmaktan çok davranışsal bir görünüm sergileyecektir. } \\
\text { Peki, ne yapılmalıdır? Bu ve benzeri sözcükler ders kitaplarından çıkarılmalı mıdır? } \\
\text { Elbette ki bu ve benzeri sözcükler de öğretilecektir ve ders kitaplarında olmalıdır. } \\
\text { Burada söylemek istediğimiz şey; zamanın, yerin ve öğretim yönteminin doğru ve } \\
\text { öğrenci düzeyine uygun olmasıyla ilgilidir. }\end{array}$ \\
\hline $\begin{array}{l}\text { Türkçe } 8 \text { (Şahin, 2013: } \\
\text { 11) Meraklı Pandora ve } \\
\text { Konuşan Sandık adlı } \\
\text { metinde... }\end{array}$ & $\begin{array}{l}\text { "Güzel Pandora, merak içinde, Hermes'in omuzundaki gösterişli sandığa bakıyor, } \\
\text { gözlerini sandıktan ayıramıyordu" tümcesindeki omuzunda sözcügünün yazımı } \\
\text { ünlü düşmesi kuralına uymamaktadır. Doğrusu omzunda biçiminde olmalıdır. }\end{array}$ \\
\hline $\begin{array}{l}\text { Türkçe } 8 \text { (Şahin, 2013: } \\
\text { 71) Ceviz adlı } \\
\text { metinde... }\end{array}$ & $\begin{array}{l}\text { "...uzun bir müddet bizi hayretle, korku ile seyrettikten sonra yavaş yavaş, ağır ağır, } \\
\text { bir yaşlı adam ağırbaşlıığıyla bize doğru ilerlemeye başladı" tümcesinde yer alan } \\
\text { iki durum belirteci de aynı anlamdadır ve gereksiz bir yineleme gibi durmaktadır. } \\
\text { İkisini aynı anda arka arkaya kullanmak yerine birini tercih etmek yeterli olabilir. }\end{array}$ \\
\hline $\begin{array}{l}\text { Türkçe } 8 \text { (Şahin, 2013: } \\
\text { 100) Bayan Hardy adlı } \\
\text { metinde... }\end{array}$ & $\begin{array}{l}\text { "Disleksisi olan çocuklar sözlükleri genellikle çok çabuk öğrenirler ama bu } \\
\text { sözcükleri başka çocukların gördüğü gibi göremezler" tümcesinde yanlışlıkla, } \\
\text { "sözlük", "sözcük" yerine kullanılmıştır. Tümce özel bir bilgi verdiğinden, okuyucu, } \\
\text { disleksisi olan çocukların gerçekten de sözlük öğrenmek gibi bir yetenekleri } \\
\text { olduğunu düşünebilir! }\end{array}$ \\
\hline $\begin{array}{l}\text { Türkçe } 8 \text { (Şahin, 2013: } \\
\text { 100) Bayan Hardy adlı } \\
\text { metinde... }\end{array}$ & $\begin{array}{l}\text { Burada daha önce } 5 \text {. Sınıf Türkçe dersi kitabında karşılaştığımız yanlışlığın } \\
\text { yinelendiğini görüyoruz: "Algıladığım dünya, sözcükler adıverilen şekillerle dolu } \\
\text { harika bir dünyaydı ve bildiğim sözcük sayısı annemin ve babamın öğrenme } \\
\text { yeteneğim konusunda çok iyimser olmalarına neden oluyordu." (...) "çok iyimser } \\
\text { olmalarını sağlıyordu" ifadesi tercih edilebilirdi. }\end{array}$ \\
\hline $\begin{array}{l}\text { Türkçe } 8 \text { (Şahin, 2013: } \\
\text { 113) Çocuktum } \\
\text { Ufacıktım Top } \\
\text { Oynadım Acıktım adlı } \\
\text { metinde... }\end{array}$ & $\begin{array}{l}\text { "Kardeşini kıskanmasın ve uğur getirsin diye kuşaklar boyu, uygulanan belki de } \\
\text { Türklerin Şaman döneminden kalma bir âdetti bu ayak gösterme konusu." Bu } \\
\text { tümcede, "kuşaklar boyu uygulanan" söz öbeği, "âdet" isminin tamlayanı } \\
\text { durumundadır ve virgülle ayrılması yanlıştır; virgülün kaldırılması gerekmektedir. }\end{array}$ \\
\hline
\end{tabular}

Buraya yanlış ya da bir eksikliği olduğunu düşündüğümüz için aldığımız örnekler, kitapların editör ya da yazarları tarafından doğru bilindiği veya doğru sanıldığı için konulmamıştır. Zaten o metinleri bizzat kaleme alanlar da onlar değildir. Yoksa editör ve kitap sorumluları da neyin doğru neyin yanlış olduğunu elbette ki en az bizim kadar iyi bilmektedirler; bununla beraber, sorunun bilmek değil, uygulamada gerekli hassasiyeti göstermek olduğunu vurgulamak isteriz. Dolayısıyla öne 
Illköğretim Türkçe Dersi Kitaplarındaki Türkçe Yanlışları ve Eksiklikler Üzerine Bir İnceleme

çıkan nokta, metinlerin daha bir titizlikle incelenmesi ve seçilmesi oluyor. Buna ek olarak, eğer gerekiyorsa metinlerin özgün biçimlerine müdahale edilerek yeniden düzenlenmeleri de gerekiyor. Diğer yönüyle bazen baskıda, dizgide gözden kaçan yazım yanlışları tabii ki olabilmektedir; ancak bunun geçerli bir mazeret gibi kabul edilmesini de doğru bulmuyoruz.

\section{Ders Kitaplarındaki Etkinliklere Dair}

Ders kitaplarının en önemli bileşenlerinden biri de içerdikleri etkinliklerdir. Etkinlikler, konunun anlaşılıp anlaşılmadığını denetlemenin yanı sıra, kazanımlar açısından da pekiştireç görevi görürler. Dört temel dil becerisini kazandırmada etkinlikler en büyük paya sahiptir. Öğrenme/Öğretme kavramları da etkinlikler açısından oldukça önemlidir: "Yeni Türkçe Öğretim Programı yapılandırmacı bir öğrenme kuramı temel alınarak hazırlanmış olduğu için öğrenci merkezli bir anlayış odak alınarak hazırlanmıştır. Bu bakımdan öğretme kavramından çok öğrenme kavramı daha temel bir kavram durumuna gelmiştir. Hazırlanan ders kitapları da öğrenme etkinliklerini içerir bir biçimde hazırlanmıştır" (Ülper, 2010: 55). Burada hemen belirtmemiz gerekir ki etkinliklerin öğrenci merkezli olması gerektiği ya da öğrenci merkezli olduğu söylense de merkezde fiziksel olarak ders kitabının olduğu gerçeği yadsınamaz. Nitekim yapılan inceleme ve değerlendirmeler de bu kapsamda ele alınmaktadır.

Şimdi Türkçe dersi kitaplarındaki bazı etkinliklerle ilgili önemli bulduğumuz birkaç ayrıntıyı paylaşmak istiyoruz: Dilbilgisi yanlışıklarının dışında ders kitaplarında görülen bir başka yanlışlık ise, öğrencilerden seviyelerini aşacak birtakım etkinliklerin istenmesidir. Etkinlikler "yapılandırmacı yaklaşım”ın etkisiyle hazırlanan yeni ders kitaplarında çok önemli bir yere sahiptir. Öğrenci etkinlikler sayesinde "yaparak öğrenme" şekliyle kalıcı öğrenme gerçekleştirmektedir. Fakat bazen, bu etkinliklerin nitelik ve nicelik olarak iyi düzenlenmemesinden kaynaklanan sorunlar ortaya çıkmaktadır. Örneğin; 7. sınıf Türkçe dersi kitabında "Anne Ben Çocuk Değilim” adlı konu işlenirken öğrencilerin konuyu anlamlandırabilmelerini sağlamak adına 11 tane etkinlik verilmiştir. Metne ve etkinliklere ayrılan süre göz önüne alındığında metnin ve bu kadar etkinliğin işlenmesinde süre sıkıntısı yaşanacağı açıktır. Etkinliklerin sayıca bu kadar artırılması yerine niteliklerinin öğrenci düzeylerine uygun olarak en çok yarar sağlanabilecek biçimde düzenlenmesi daha doğru olacaktır.

Etkinlik sayısı ve süreyle ilgili sıkıntılar dışında etkinliklerle ilgili bir başka sorun da etkinliklerin öğrenci düzeylerinin üzerinde olmasıdır:

5. sınıf Türkçe dersi kitabında "Aslında Hepimiz Zekiyiz" adlı konunun etkinliklerinde 7. etkinlik olarak öğrencilerden;

"Sayısal zekâm gelişmiş, ama sözel zekâm zayıf" diyen birisine sözel zekâsını geliştirmesi için neler önerirsiniz?" şeklinde bir soru sorularak öğrencilerden bu soruyu cevaplandırmaları istenmiştir. Yine aynı ders kitabında, "Düşler ve Teknoloji" adlı metin işlenirken ise; bir yetkiliye, robot ve 
androidlerle ilgili çalışmalarının devamı için ikna edici bir mektup yazmaları isteniyor. 5. sınıftaki bir öğrencinin böyle bir çalışma ortaya koyabilmesi için öncelikle "mektup" türünü bilmesi gerekmektedir. Henüz somut işlemler döneminde olan öğrencilerin soyutlamalar yaparak teknoloji konusunda bir yetkiliyi ikna edebilecek düzeyde bir mektup yazmalarının istenmesi öğrenciler için oldukça zor bir etkinliktir.

Türküler Dolusu adlı metnin etkinlik kısmında ise öğrencilerden "memleket" kelimesinin harflerinden oluşan bir akrostiş yapmaları istenmektedir.

8. sınıf Türkçe dersi kitabında, yine etkinlik olarak, "Ben de doğa olsaydım" konulu kısa bir tiyatro yazılması istenmektedir. Bu etkinliğin de "memleket" sözcüğünün harflerinden oluşan bir akrostiş yazılmasının istenmesinden farklı olmadığı ortadır ve bu türden etkinlikler öğrencilerin genel bilgi ve beceri düzeylerinin üzerindedir. Bu yaşlardaki öğrencilerden böylesine üst becerileri beklemek öğrencileri zorlayacağı gibi başarısız olmaları durumunda derse karşı isteksizlik ve antipati geliştirmelerine de neden olabilecektir. Bu sebeple etkinlikler düzenlenirken öğrencilerin düzeyleri göz önünde bulundurulmalı ve uygun etkinliklerin seçilmesinde daha titiz davranılmalıdır.

Öğrenimlerinin henüz ikinci kademesinde bulunan öğrencilerin kullanımına sunulan ders kitaplarında, onların anlamalarını kolaylaştırmak adına daha kısa ve öz tümceler kullanılabilir. Konular işlenirken verilen metinlerdeki yabancı sözcük ağırlı̆ı̆ da göz önünde bulundurulmalı ve öğrencinin anlamasını zora sokacak düzeyde yabancı sözcük içeren metinler yerine daha yalın metinler yeğlenebilir. Aşağıya öğrencilerin düzeyinin üzerinde olduğunu düşündüğümüz birkaçörnek alıyoruz:

"Biz burada halledilmesi üstün yaradılışlar bekleyen büyük davaları bir kenara bırakalım da kendi küçük, iyi yaşama davamızı istek motoru ile nasıl yürüteceğimizden, gündelik hayatımızı daha iyiye nasıl götüreceğimizden konuşalım." (Karabıyık, 2013: 52)

“1948 yılında İnsan Hakları Evrensel Bildirgesi'nde eğitim hakkının yer alması, Birleşmiş Milletlerin sosyal, ekonomik ve kültürel hakları, medeni ve siyasal haklarla uyumlu olarak geliştirme yönündeki kapsamlı çabalarının başlangıcını oluşturmuştur." (Yangın, 2013: 13 )

“Sözleşme'nin 29. maddesi ise devletlerden, çocuğun kişiliğinin, zihinsel ve bedensel yeteneklerinin mümkün olduğunca geliştirilmesini; çocuğun insan haklarına ve temel özgürlüklere saygı duyarak anlayış, barış, hoşgörü, cinsler arası eşitlik, tüm insanlar arasında dostluk ruhuyla yetiştirilmesini ve özgür bir toplumda etkin bir yaşantıya sorumluluk üstlenecek biçimde hazırlanmasını istemektedir."(a.g.y.)

Bu tümcelerin, altıncı ve yedinci sınıf düzeyindeki öğrencilerin anlamlandırabileceğinden daha uzun $^{6}$ tümceler olduğu kanısındayız. Tümcelerin daha kısa tutulması, mümkünse sadeleştirilmesi ve verilmek istenenlerin kısa ve öz ifade edilmesi daha uygun olacaktır, düşüncesindeyiz.

\footnotetext{
${ }^{6}$ Olması gerektiği varsayılan tümce uzunlukları için bkz. (Çebi, 2006: 117).
} 


\section{Illöğretim Türkçe Dersi Kitapları ve Anadili Bilinci}

Her insanın bir dil yetisiyle doğduğu bilinmektedir. Bu dil yetisinin harekete geçirilmesi; en doğru sözlerin, sözcük havuzumuzdan başka bir deyişle sahip olduğumuz sözcük dağarcığımızdan seçilip, ifademizi yansıtan en doğru yere en doğru şekilde yerleştirilmesiyle mümkündür. İşte tam da bu noktada anadilimizi ne kadar bilinçli kullandığımızı sorgulamak gerekir. Anadili bilinci, bireyin konuştuğu dilin gereklerini bilip, bu gereklere sadık kalmak için belirli bir çaba ve emek sarf etmesinin yanı sıra -bir anlamda- bireyin konuştuğu dile saygısıyla da eşdeğerdir. Birey dilini ne kadar çok benimsemişse, kendi dilini ne kadar iyi tanımışsa, dilini kullanma yeteneği de o ölçüde artacaktır. Dili tanımak; dilin kaynaklarını, zenginliklerini bilmekle mümkün olabilir.

$\mathrm{Bu}$ arada hemen belirtmek gerekir ki bilgisayar teknolojisinin gelişmesi, internet seçeneklerinin artıp çoğu insanın kısa bir sürede çok fazla bilgiye ulaşabilir hale gelmesi de dil kullanma alışkanlıklarımızda farklılaşmaya neden oldu. Günümüzde sosyal iletişim sitelerine üyeliğin her insan için bir zorunluluk gibi görülmesi insanların sosyal ortamlara bağlılı̆ını daha da arttırdı. Ortaya da yalnızca sosyal ağlarda kullanılan bir sosyal medya dili çıkıverdi. Sosyal medya dili denilen bu dil, var olan anadilimizin bir biçimde farklılaşmaya başlamasına da ortam hazırladı. Sosyal medya kullanıcısı olmayan bireylerle, sürekli sosyal medyada olan bireylerin iletişiminde zaman zaman uyumsuzluklar ve buna bağlı olarak iletişim kopuklukları belirmeye başladı. Türkçe bilgi ve becerisine daha doğrusu anadili bilincine sahip olmamaktan kaynaklanan bu kopuklukları ve sorunları önlemek ya da en aza indirebilmek için neler yapılabilir? Ya da anadili bilinci bu yeni ve beklenmedik gelişmeler ${ }^{7}$ karşısında nasıl korunabilir?

Öncelikle bireyin kendi anadilini sevip, onun egemenlik alanının genişliğini ve etkileşim gücünün çok yönlü olduğunu bilmesi gerekir. Dilimize giren yeni sözcüklerin kendi köklerimizde benzerlerinin bulunması ve bunun farkına varılması gerekir. Bu farkındalığı oluşturabilmek için de öncelikle insanımıza çocukluktan itibaren anadili bilincini aşılamamız gerekir. Aileden sonra çocuğun ikinci evi okulu olduğundan, çocuğa anadili bilinci kazandırabilmek için uygun ortamı oluşturmak tüm öğretmenlerimizin başlıca görevlerinden biri olmaktadır. Bu görevde en büyük sorumluluk Türkçe dersine, o dersin öğretmeni olan Türkçe öğretmenine yani anadili öğretmenine düşmektedir. Türkçe öğretmenleri anadili bilincini yansıtan canlı örnekler olmalıdır. Bu anlamda derste kullandıkları ana kaynak olan Türkçe dersi kitapları da canlı birer anadili bilinci kazandırma kitabı olmalıdır. Türkçe öğretmenlerinin esas sorumluluk alanı olan 5, 6, 7 ve 8. Sınıf öğrencilerinin temel kaynağı olan Türkçe dersi kitaplarını tam da bu bağlamda incelemek gerekir.

\footnotetext{
${ }^{7} \mathrm{Bu}$ arada sorunu, sadece sosyal medyadaki yetersiz Türkçe kullanımına indirgediğimiz düşünülmemelidir. Türkçe bilgi ve becerisindeki birçok yetersizlik ve olumsuzluğu başka alanlarda da görmek olasıdır.
} 
Burada incelememize konu olan illköğretim 5, 6, 7 ve 8. sınıf Türkçe dersi kitapları 2012-2013 Eğitim-Öğretim yılında Milli Eğitim Bakanlığı'nın hazırladığı ve ilk sırada tavsiye ettiği kitaplardır ${ }^{8}$. Türkçe dersi kitaplarındaki metinlerin tamamının anadili bilinciyle olan ilişkisini değerlendirdiğimizde, bu metinlerin çoğunun bu işlevi dolaylı yoldan yerine getirdiğini görmekteyiz; ancak burada, bu yazıda ele aldığımız metinler ise anadili bilincini dolaylı olarak değil, doğrudan geliştirebilecek ve özellikle dili konu edinen kaynak metinlerdir. Nitekim değerlendirmemizde sözü edilen metinlerin hepsi de "dil" konusunu işlemiştir. Metinlerin konusu yalnızca dil olduğu için biz bu metinleri, anadili bilincini geliştirmeye yönelik metinler olarak değerlendirdik. Söz konusu metinlerde, bazen bir deyimin hikâyesi, bazen Türkçenin söyleniş özelliklerine dikkat çeken bir tekerleme, bazen de dili doğru ve etkili kullanmanın önemi üzerinde durulmuştur. Elbette ki Türkçe dersi kitaplarında farklı edebi türlerin örneklendirilmesiyle de dil bilinci oluşturulmaya çalışılmış olabilir; ancak burada amacımız; dil bilincine yönelik farklı türlerdeki metinlerin seçimi değildir. Asıl amaç, "içerik" ya da "konu" yönüyle hedefi; öğrencileri anadili bilincine ulaştırmak olduğu varsayılan metinlerin tespitidir. Değerlendirmede, etkinliklerin yer aldığı çalışma kitapları veya öğretmen kılavuz kitapları değil; Türkçe dersinin omurgasını yani metinleri barındıran Türkçe dersi kitapları incelenmiştir.

Anadili bilincini geliştirmeye yönelik olduğu varsayılan metinlerin özellikleri aşağıdaki tabloda verilmiştir:

Tablo-2 Anadili bilincine yönelik metinler ve özellikleri

\begin{tabular}{|c|c|c|}
\hline Sinıf & Metnin Adı & Metnin Temel Özelliği \\
\hline \multirow{5}{*}{ 5. Sinıf } & Pireyi Deve Yapmak (s.14) & $\begin{array}{l}\text { "Pireyi Deve Yapmak" deyimi metinde örneklerle açıklanmış; } \\
\text { öğrencilere milli kültürümüzün ögelerinden olan deyimlerle anadili } \\
\text { bilinci aşılanmaya çalışılmıştır. }\end{array}$ \\
\hline & $\begin{array}{c}\text { Atatürk ve Türk Dili } \\
\text { Serbest Okuma Metni (s.39) }\end{array}$ & $\begin{array}{l}\text { Atatürk'ün Türk dilini geliştirmek için yaptığı çalışmalar detaylı bir } \\
\text { şekilde anlatılmış; Türkçenin güzelliği, değişimi ve dil bilincinin } \\
\text { önemi ile ilgili bilgiler verilmiştir. }\end{array}$ \\
\hline & Dilim Dilim Güzel Dilim (s.60) & $\begin{array}{l}\text { Metinde günümüz Türkçesinin sorunlarına yer verilmiştir. Bu } \\
\text { sorunlarla birlikte dil bilincinin önemine yönelik çeşitli öneriler de } \\
\text { metin içerisinde mevcuttur. Dilde yabancılaşma gibi güncel dil } \\
\text { sorunlarına Türkçe sözcüklerle çözüm aranmaya çalışılmıştır. }\end{array}$ \\
\hline & $\begin{array}{c}\text { Tekerlemeci Dayı } \\
\text { Serbest Okuma Metni (s.74) }\end{array}$ & $\begin{array}{l}\text { Metinde tekerleme türünden yola çıkılarak Türkçenin güzel } \\
\text { yönlerine ve söyleniş özelliklerine değinilmiştir. Metin sonunda, dili } \\
\text { etkili kullanmanın bize ve çevremizdekilere teknolojik aletlerden } \\
\text { daha fazla mutluluk vereceği vurgulanmıştır. }\end{array}$ \\
\hline & Burada Dur (s.98) & $\begin{array}{l}\text { Mekân adlandırılmasında Türkçemizin güzel söyleyiş özelliklerinin } \\
\text { yansımalarına örnekler verilmiş; bu sayede öğrencilerin ana } \\
\text { dillerinin güzelliklerini fark etmelerine ortam hazırlanmıştır. }\end{array}$ \\
\hline 6. Sinıf & $\begin{array}{c}\text { Atasözü ve Deyimlerde Kalan } \\
\text { Mahalleler (s.98) }\end{array}$ & $\begin{array}{l}\text { Metinde komşuluk kavramı ile ilgili atasözü ve deyimler } \\
\text { anlatılmıştır. Bu atasözü ve deyimlerin oluşumlarına da eserde yer } \\
\text { verilmiştir. }\end{array}$ \\
\hline
\end{tabular}

\footnotetext{
${ }^{8}$ Milli Eğitim Bakanlığı́nın İnternet üzerinden hizmete sunduğu ilk ve orta öğretim ders kitapları için bkz. http://www.meb.gov.tr/duyurular/duyuruayrinti.asp?ID=8947 (Erişim: 13.06.2014).
} 


\begin{tabular}{|c|c|c|}
\hline \multirow{5}{*}{ 7. Sinıf } & Tat/ı Dil (s.10) & $\begin{array}{l}\text { Dili doğru ve etkili kullanmanın önemi üzerinde durulmuş, "tatlı } \\
\text { dilli insan kavramı" açıklanmıştır. }\end{array}$ \\
\hline & Öyle Denmez (s.14) & $\begin{array}{l}\text { Metinde, kalıp sözlerin kullanımı, dilimizin söyleyiş özellikleri ve } \\
\text { dilimize anlam katan ayrıntılar örneklerle sunulmuştur. }\end{array}$ \\
\hline & $\begin{array}{l}\text { Bir Iletişim Biçimi Olarak } \\
\text { Karikatür (s.18) }\end{array}$ & $\begin{array}{l}\text { Dil kavramı üzerinden yola çıkılarak kişinin anadilinin önemine } \\
\text { değinilmiştir. }\end{array}$ \\
\hline & Atatürk ve Türk Dili (s.38) & $\begin{array}{l}\text { Atatürk'ün Türk diline olan bağlılığı ve Türkçenin önemi esere konu } \\
\text { edilmiştir. }\end{array}$ \\
\hline & $\begin{array}{l}\text { Bol Deyimli Bir Yazı } \\
\text { Serbest Okuma Metni (s.82) }\end{array}$ & $\begin{array}{l}\text { Metinde deyim kullanmanın dilimizin zenginliğine işaret ettiği } \\
\text { söylenmiş, çeşitli deyimlerin kullanım şekillerine örnekler } \\
\text { verilmiştir. Buradaki örneklerin anadili bilinci oluşturmaya katkı } \\
\text { sağladığı/sağlayacağı düşünülmektedir. }\end{array}$ \\
\hline 8. Sinıf & Bilgisayar Yalnızlığı (s.85) & $\begin{array}{l}\text { Teknolojinin gelişmesi ile insanlar arasındaki iletişim zayıflığından } \\
\text { ve dili kullanma yoksunluğundan bahsedilmiştir. Günümüz } \\
\text { insanlarının aşığı oldukları bilgisayarın divan şiirlerindeki sevgilinin } \\
\text { yerini aldığı söylenmiştir. Şiirlerin, şarkıların, konuşmanın, kısacası } \\
\text { dil kullanımının önemine değinilmiştir. }\end{array}$ \\
\hline
\end{tabular}

Öte yandan 5, 6, 7 ve 8. Sınıf kitaplarında yer alan temalar ve bu temalar içinde doğrudan dili konu edinen ya da anadili bilincini kazandırmaya yönelik metinler nicelik olarak da şöyledir:

Tablo-3: Ilköğretim 5. Sınıf Türkçe dersi kitabındaki anadili bilincine yönelik metinler

\begin{tabular}{|c|c|c|c|}
\hline \multirow{9}{*}{ 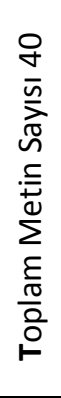 } & Temalar & Anadili bilincine yönelik metinler & Sayısı \\
\hline & Birey ve Toplum & Pireyi Deve Yapmak & 1 \\
\hline & Atatürk & Atatürk ve Türk Dili & 1 \\
\hline & Sağlık ve Çevre & $\varnothing$ & 0 \\
\hline & Değerlerimiz & Dilim Dilim Güzel Dilim, Tekerlemeci Dayı & 2 \\
\hline & Dünyamız ve Uzay & $\varnothing$ & 0 \\
\hline & Güzel Ülkem Türkiye & Burada Dur & 1 \\
\hline & Yenilikler ve Gelişmeler & $\varnothing$ & 0 \\
\hline & Güzel Sanatlar & $\varnothing$ & 0 \\
\hline \multicolumn{3}{|c|}{ Anadili bilincine yönelik olduğu düşünülen toplam metin sayısı } & 5 \\
\hline
\end{tabular}

Tablo-4: Illköğretim 6. Sınıf Türkçe dersi kitabındaki anadili bilincine yönelik metinler

\begin{tabular}{|c|c|c|c|}
\hline \multirow{8}{*}{ 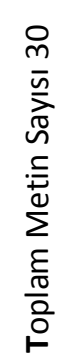 } & Temalar & Anadili bilincine yönelik metinler & Sayıs \\
\hline & Okuma Kültürü & $\varnothing$ & 0 \\
\hline & Atatürk & $\varnothing$ & 0 \\
\hline & Sevgi & $\varnothing$ & 0 \\
\hline & Duygular & $\varnothing$ & 0 \\
\hline & Zaman ve Mekân & Atasözü ve Deyimlerde Kalan Mahalleler & 1 \\
\hline & Doğa ve Evren & $\varnothing$ & 0 \\
\hline & \multicolumn{2}{|c|}{ Anadili bilincine yönelik olduğu düşünülen toplam metin sayısı } & 1 \\
\hline
\end{tabular}

Tablo-5: ilköğretim 7. Sınıf Türkçe dersi kitabındaki anadili bilincine yönelik metinler

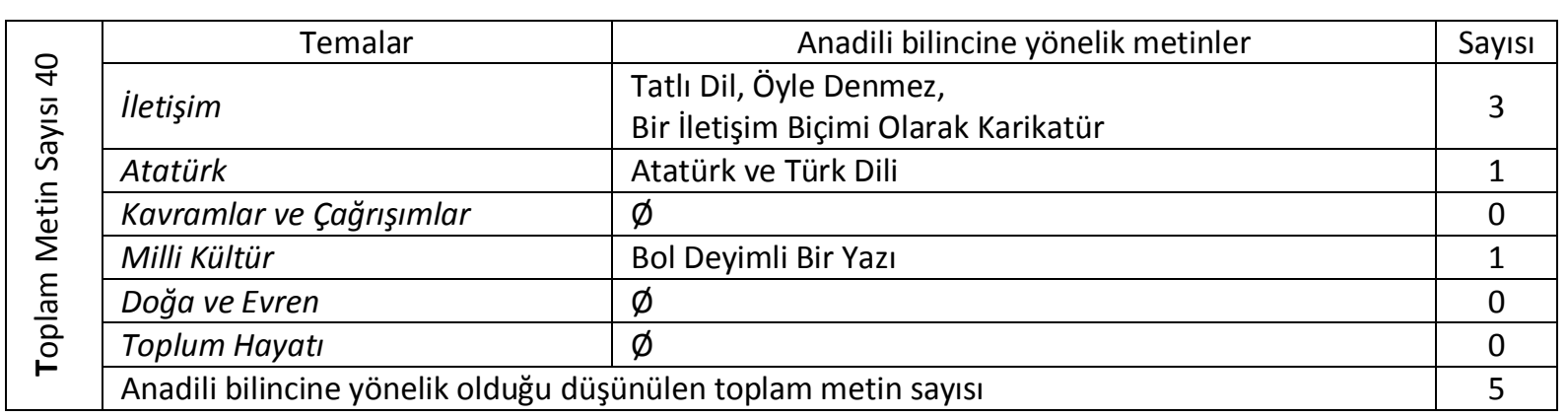


Tablo-6: Illköğretim 8. Sınıf Türkçe dersi kitabındaki anadili bilincine yönelik metinler

\begin{tabular}{|c|c|c|c|}
\hline \multirow{8}{*}{ 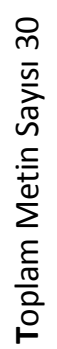 } & Temalar & Anadili bilincine yönelik metinler & Sayısı \\
\hline & Zaman ve Mekân & $\varnothing$ & 0 \\
\hline & Atatürk & $\varnothing$ & 0 \\
\hline & Milli Kültür & $\varnothing$ & 0 \\
\hline & Toplum Hayatı & $\varnothing$ & 0 \\
\hline & Bilim ve Teknoloji & Bilgisayar Yalnızlığı & 1 \\
\hline & Kişisel Gelişim & $\varnothing$ & 0 \\
\hline & \multicolumn{2}{|c|}{ Anadili bilincine yönelik olduğu düşünülen toplam metin sayısı } & 1 \\
\hline
\end{tabular}

Grafik 1: Ilköğretim 5, 6, 7 ve 8. Sınıf Türkçe dersi kitaplarındaki anadili bilincine yönelik metinler toplamı

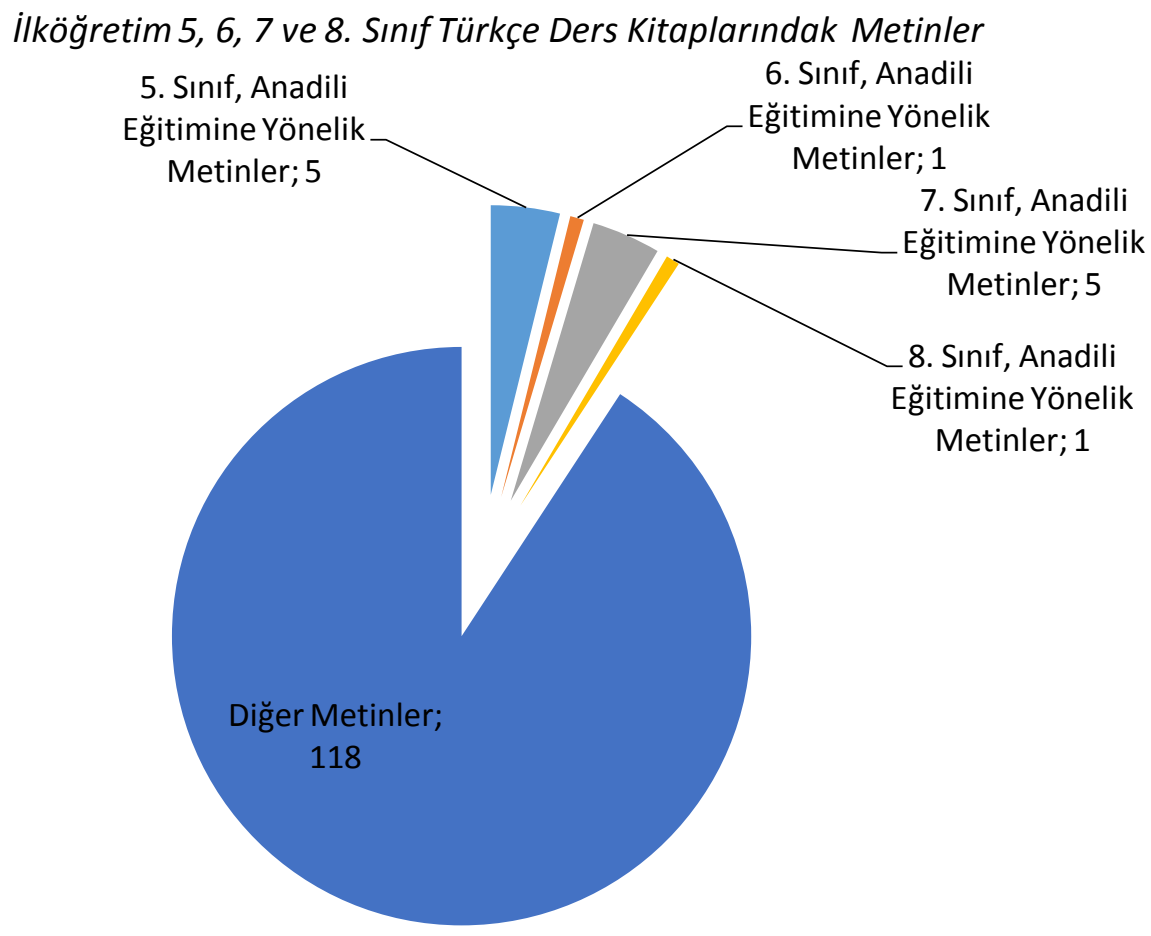

5. Sınıf, Anadili Eğitimine Yönelik Metinler $\square$ 6. Sınıf, Anadili Eğitimine Yönelik Metinler

7. Sınıf, Anadili Eğitimine Yönelik Metinler $\square$ 8. Sınıf, Anadili Eğitimine Yönelik Metinler

Diğer Metinler

Yukarıda verilen grafik ve tablolardan şu sonuçlar çıkarılabilir:

- Türkçe dersi kitaplarında öğrencilere anadili bilinci kazandırabilecek nitelikli metin sayısı sınırlıdır. Bu durum da kitapların ana dili bilinci kazandırılmasına yönelik işlevini zayıflatmaktadır.

- Türkçe dersi kitaplarında anadili bilinciyle ilgili yer alan 12 metnin 2 tanesi serbest okuma metnidir. Bu metinler serbest okuma metni olduğu için, her ikisinde de öğrencileri konuya odaklayabilecek değerlendirme çalışmaları yoktur. 
- Anadili bilincine yönelik metinlerin 5. ve 7. sınıf kitaplarında daha fazla olduğu görülmektedir. Beşinci sınıfta öğrencilerin kitaplarında bulunan anadili bilincine yönelik metinler daha da fazla olmalıdır. Çünkü bu dönem, anadili bilincinin oluşturulması açısından oldukça önemlidir.

- 6 ve 8. Sınıf kitaplarında anadili bilincine yönelik metinler sadece birer tanedir. 8. Sınıf Türkçe dersi kitaplarında sadece bir metnin olması daha da düşündürücüdür. Nitekim bu dönem, öğrencilerin tam da gençliğe adım attıkları kritik bir dönemdir. Sekizinci sınıftan sonra gelen lise döneminde değişecek sosyal çevreyi düşünürsek; öğrencilere anadili bilincinin korunmasına yönelik daha fazla metin sunulabilir.

- "Değerlerimiz" ve "iletişim" temalarında yer alan örnek metinlerin diğerlerine oranla daha fazla olması, bizlere dilin toplum ve iletişim boyutu hakkında da bilgi vermektedir.

Öte yandan, anadili bilinci ve kazanımlarıyla ilgili tespit ve öneri olarak da şunları söyleyebiliriz:

1- Dilimizin farkına varmak ve onu yerli yerinde kullanmak hepimizin temel görevidir. Dilimizin en küçük ses parçacığının dahi farklı bağlamlarda farklı anlamlar ortaya çıkarması dilimizin zenginliklerinden biridir. Birey anadili konusunda bilinçli değilse bu zenginlikleri ne önemseyecek ne de onlardan yararlanabilecektir.

2- Anadili bilincinin bireylere çok küçük yaşlarda kazandırılması için çaba gösterilmesi gerekmektedir. Hatta bunun için devlet desteğiyle belirli yaş grupları için farklı eğitimler tasarlanabilir. Örneğin; okul öncesi dönemde henüz okula gitmeyen çocuklar için her ilde, ilin yöresine uygun aylık eğitim programları düzenlenebilir. Bu programlarda yer alacak olan eğitimciler, sorumlu oldukları yaş grubuna göre tekerleme yarışması, sesleri doğru çıkarabilme yarışması, çocuk şarkılarını en iyi söyleme yarışması gibi çeşitli etkinliklerle çocukların dille olan ilişkisini arttırabilirler.

3- Okullarda, "Ayın Türkçeyi En Doğru Kullanan Öğrencisinin Seçilmesi" gibi etkinlikler düzenlenebilir. Bu sayede öğrenciler arasında yarışma psikolojisiyle anadili bilincini geliştirmeye yönelik bir çalışma yapıımış olur.

4- Öğrencilerden Türkçe performans ödevleri yerine, onlarla birlikte bir Türkçe kitabı oluşturma çalışması yapılabilir. Bu amaçla, her öğrencinin yılsonuna kadar kitapta bulunmasını istediği bir metni kendince değerlendirme çalışmalarıyla beraber hazırlayıp getirmesi sağlanabilir. Bu çalışma, öğrencinin Türkçe dersi kitabının varlığından haberdar olmasını sağladığı gibi, bizim onların estetik zevki hakkında bilgi sahibi olmamıza da ortam hazırlar.

5- Türkçe dersi kitaplarında bulunan nitelikli metin sayısı bir hayli düşüktür. Bu sorunun giderilmesi için sadece ders kitapları ile meşgul olan, ders kitapları ile gerekirse kelimesi kelimesine ilgilenen komisyonların kurulması gerekir. Türkçe dersi kitaplarının işlevsellik özelliğinin farkına varılıp, kitaplar içerik yönüyle bu amaca uygun hazırlanmalıdır. 
6- Türkçe dersi kitaplarında yer alan etkinliklerin uygulamaya dayalı olması, öğrencilerin zihnindeki kalıcılığı da attıracaktır. Kitaplardaki metinlerin içerikleri "yaparak-yaşayarak öğrenme" yöntemine uygun olmalıdır. Yani öğrenci metinde geçen olayları günlük hayatıyla ilişkilendirebilmelidir.

\section{Sonuç}

Eğitim-öğretim sisteminin temel ögelerinden biri olan ders kitapları günümüzde "biçimsel görünüm" olarak olması gereken düzeye yaklaşmış olsa da, "bilimsel içerik" ile "dil ve anlatım" yönünden daha titiz ve özenli davranılması gerektiğini düşünmekteyiz. Gerek bazı dikkatsizlikler gerekse bazı yanlış tercihler ve hatalar kitapların istenilen düzeyin altında kalmasının sebepleri arasındadır. Temennimiz o dur ki, eğitim öğretim sisteminin bu önemli materyali, istenilen nitelikte hazırlanarak öğrencilerin ve öğretmenlerin istifadesine sunulur ve öğrenciler kendi seviyelerine uygun tam ve doğru bilgileri, ders kitapları yardımıyla ve öğretmenlerinin yönlendirmesiyle edinirler. Ancak her şeye rağmen yine de en önemli nokta öğrencilere anadili bilincinin kazandırılmasıyla ilgilidir: Türkçe dersi kitaplarına, anadili Türkçe konusunda duyarlıık sahibi bilinçli bireylerin yetiştirilmesi amacıyla nitelikli metinler konulmalıdır. Nitekim anadili bilinci konusunda bir duyarılık ve farkındalık yaratılamadığı içindir ki bugün ilköğretimden başlayıp lisansüstü eğitim dâhil hemen her alanda Türkçenin doğru, yerinde ve etkin kullanımıyla ilgili birçok sorunla boğuşulmaktadır.

\section{Kaynakça:}

Alacalı, O. (2013), illköğretim Türkçe 5 Ders Kitabı, Ada Yayınları, Ankara.

Altan, A. ve ark., (2012), ilköğretim 8. Sınıf Türkçe Ders Kitabı, M. Özbay (Ed.), MEB Devlet Kitapları, 5. Baskı, Ankara.

Arı, G., (2010), "Türkçe Ders Kitaplarında Fiziksel ve Biçimsel Görünüm", Türkçe Ders Kitabı Çözümlemeleri içinde, H. Ülper (Ed.), Pegem Akademi, Ankara.

Başar, S., Zeybek Köken S., (2012), illköğretim 5. Sınıf Türkçe Ders Kitabı, H. Akyol (Ed.), MEB Devlet Kitapları, 3. Baskı, Ankara.

Çebi, A., (2006), "Ders Kitaplarında Dil ve Anlatım", Konu Alanı Ders Kitabı Incelemesi içinde, Ö. Demirel ve K. Kıroğlu (Ed.), Pegem A Yayıncılık, Ankara.

Çiçek, M., Bağçeci, B., (2013), "Anadili Bilme Düzeyi İle Yabancı Dil Başarısı Arasındaki İlişkinin İncelenmesi", JASSS (International Journal of Social Science), Vol. 6 Issue 5, pp. 923-935, Lorient, FRANCE.

Dane, A., Doğar, Ç., Balkı, N. (2004), "ilköğretim 7. Sınıf Matematik Ders Kitaplarının Değerlendirmesi”, Erzincan Eğitim Fakültesi Dergisi Cilt-Sayı: 6-2, Erzincan.

Deniz, K. (Ed.), (2012), Ilköğretim 6. Sınıf Türkçe Ders Kitabı, Komisyon, MEB Devlet Kitapları, 2. Baskı, Ankara.

Deniz, K. (Ed.), (2012), ilköğretim 7. Sınıf Türkçe Ders Kitabı, Komisyon, MEB Devlet Kitapları, 1. Baskı, Ankara.

Duman, T., Karakaya, N., Çakmak, M., Eray, M. ve Özkan, M. (2001) Konu Alanı Ders Kitabı incelemesi, L. Küçükahmet (Ed.), Nobel Yayın Dağııım, s.10-40, Ankara. 
Illköğretim Türkçe Dersi Kitaplarındaki Türkçe Yanlışları ve Eksiklikler Üzerine Bir İnceleme

Yıldırım, M.C., Akın, Ö.M., Özdaş, F. (2011) IIlköğretim Okulları Ders Kitapları, Öğrenci Çalışma Kitapları ve Öğretmen Kılavuz Kitaplarının Branşlara Göre Incelenmesi Çalıştayları Raporu, A. Ekinci ve M. A. Öter (Ed.), Dicle Üniv. Yay. Diyarbakır.

İşeri, K., (2010), "Türkçe Ders Kitaplarında Resimler", Türkçe Ders Kitabı Çözümlemeleri içinde, H. Ülper (Ed.), Pegem Akademi, Ankara.

Karabıyık, F., (2013), ilköğretim Türkçe 6 Ders Kitabı, Evren Yayıncılık, Ankara.

Kılıç, A., Seven S., (2004) Konu Alanı Ders Kitabı Incelemesi, Pegem A Yayıncılık, Ankara.

Şahin, D., (2013). Ilköğretim Türkçe Ders Kitabı 8, Ankara.

Ülper, H., (2010), "Türkçe Ders Kitaplarındaki Etkinlikler", Türkçe Ders Kitabı Çözümlemeleri içinde, H. Ülper (Ed.), Pegem Akademi, Ankara.

Yangın, B., Celepoğlu, A., Türkyılmaz, F. (2012) IIlköğretim Türkçe 7 Ders Kitabı, Ankara. 